\title{
Effect of Increasing Degradable Nitrogen from Adding Urea to the Ration of Awassi Ewes in Milk Yield and some Components
}

\author{
Al-Hafz, Maher A.K. Mohammed W. M. Ali \\ Dept. of Animal Prod. College of Agric. \& Forestry Mosul - Iraq \\ Email: Mohammed.waad88@gmail.com
}

\begin{abstract}
This experiment conducted at $1 / 12 / 2017$ to $4 / 3 / 2018$ by using 30 ewes with their lambs. The weights of the ewes between (46-51) $\mathrm{Kg}$ and the ages between (3-5) years, to study the effect of increasing degradable Nitrogen from adding urea to the food of Awassi ewes milk yield and components. The experiment done by three levels of Nitrogen degradable (low, 0\% urea) (mid, 0.75\% urea), (high, 1.5 urea). and by three treatments each of them consists of 10 ewes.

The results indicated a significant increase $(\mathrm{p} \leq 0.05)$ in weekly, monthly and commercial yield for the treatment of high degradable protein.

For the milk components during sucking and after weaning (fat, protein, lactos, S.N.F) the results revealed non significant differences. The adding of urea to the ration of awassi ewes in creased milk production.
\end{abstract}

Keyword: Fat, Protein, Lactos

Received: 9/12/ 2018, Accepted: 21/1/2019

\section{INTRODUCTION}

The production of milk was one of the important characteristics for lambs growth and for human needs for taking large quantities of milk. So the sheep breeders worked hard to increase the milk production (Al-Saegh and Al-Kass, 1992).

The best way to increase the protein rate in the food by adding different Oil Seed meal, but they were very expensive and their quantities were very little, also they were imported. Accordingly the scientists made many experiments to provide the needs of ruminants of protein frome cheap and non protein nitrogen source, So they depended on ability of organisms in rumen of animal to make a pactirial protein specialy from urea because it was available and very cheap and it was rich in nitrogen $46 \%$ and contained protein equiv 292\% (Al-Hafz, 1992).

The Awassi sheep group was one of the most important kinds in lands semiarid lands of the middle east countries, and they have a good meat and milk, they can live with different environmental systems and they're resistant to diseases and dare the high temperatures, for that, they encouraged the sheep breeders on their breeding (Lafi, etal., 2009) and (FAO, 2006).

The aim of this experiment is to study the effect of increasing degradable nitrogen from adding urea to the food of awassi ewes in milk yield and some components.

The research is part of MS.C thesis. 


\section{MATERIALS AND METHODS}

This study was done in afield of one breeder in Tal - yara village which affiliated to Baasheka from 1/12/2017 to 14/3/2018. 30 Awassi ewes were used in this study, they were divided into three treatments, and the table (1) show percentage of components of the bush and chemical analysis

Table (1) Ingredients and chemical composition of diets

\begin{tabular}{|c|c|c|c|}
\hline $\begin{array}{c}\text { Treatments } \\
\text { Item }\end{array}$ & $\begin{array}{c}\text { Treat. (1) } \\
0 \% \text { urea } \\
\text { (Low D.) }\end{array}$ & $\begin{array}{c}\text { Treat. (2) 0.75\% } \\
\text { urea (Mid D.) }\end{array}$ & $\begin{array}{c}\text { Treat. (3) } \\
1.5 \% \text { urea } \\
\text { (High D.) }\end{array}$ \\
\hline Barly & $65 \%$ & $65 \%$ & $65 \%$ \\
\hline Wheat bran & $32.25 \%$ & $31.5 \%$ & $30.75 \%$ \\
\hline Urea & $0 \%$ & $0.75 \%$ & $1.5 \%$ \\
\hline Food salt (NaCl) & $0.75 \%$ & $0.75 \%$ & $0.75 \%$ \\
\hline Calcium blocks $\left(\mathrm{CaCo}_{3}\right)$ & $1 \%$ & $1 \%$ & $1 \%$ \\
\hline Bentonite & $1 \%$ & $1 \%$ & $1 \%$ \\
\hline \multicolumn{4}{|c|}{ Chemical Composition } \\
\hline CP\% & 11.59 & 13.60 & 15.60 \\
\hline DM\% & 91.20 & 91.43 & 91.58 \\
\hline OM\% & 95.17 & 95.33 & 95.41 \\
\hline CE\% & 17.23 & 17.19 & 17.15 \\
\hline EE\% & 2.39 & 2.51 & 2.43 \\
\hline Ash\% & 4.36 & 4.42 & 4.33 \\
\hline RDP\% & 9.14 & 11.15 & 13.18 \\
\hline RUP\% & 2.45 & 2.44 & 2.10 \\
\hline D.P energy gm D.P/ M.J & 8.76 & 10.76 & 12.80 \\
\hline
\end{tabular}

* Means with different subscripts vertically differ $(\mathrm{p} \leq 0.05)$.

Percent calculated for DM, OM, CP, EE and Ash laboratory as (AOAC, 2000) and it was calculated NE and D.P. energy depend on DM (AL-Khawaja, etal., 1987).

Estimated the proportions of milk components by (milkana) machine. Data were analyzed by using (C.R.D) according to what was stated in (Al-Rawi and Khallafallah, 1980), and used the mathematical model

Yij $=\mu+\mathrm{ti}+$ eij

Yij $=$ Samples.

$\mu=$ Samples means.

$\mathrm{ti}=$ The effect of treatment and it means the effect of urea.

eij $=$ The random trial error value.

And using the test of Duncan (Duncan, 1955), and using the analysis program (SAS, 2003). 


\section{RESULTS AND DISCUSSION}

\section{Milk production:}

The results indicated a significant increase $(\mathrm{p} \leq 0.05)$ in daily and weekly milk production since the fourth week till the end of experiment for the behalf of high degradable protein which compared with the behalf of mid degradable protein and the behalf of low degradable protein, as seen in table (2).

Table (2) The effect of increasing degradable Nitrogen in weekly milk production (gm)

\begin{tabular}{|c|c|c|c|c|c|c|}
\hline \multirow{2}{*}{ Groups } & \multicolumn{6}{|c|}{ Weeks } \\
\cline { 2 - 7 } & 2 & 4 & 6 & 8 & 10 & 12 \\
\hline Group (1) & 473 & $597 \mathrm{~b}$ & $664 \mathrm{ab}$ & $669 \mathrm{ab}$ & $330 \mathrm{c}$ & $368 \mathrm{~b}$ \\
0\% urea & \pm & \pm & \pm & \pm & \pm & \pm \\
(Low Dig) & 55.12 & 68.36 & 71.80 & 73.07 & 27.13 & 40.24 \\
\hline Group (2) & 589 & $602 \mathrm{~b}$ & $632 \mathrm{~b}$ & $592 \mathrm{~b}$ & $481 \mathrm{~b}$ & $422 \mathrm{~b}$ \\
0.75\% urea & \pm & \pm & \pm & \pm & \pm & \pm \\
(Mid Dig) & 55.99 & 41.46 & 50.43 & 55.77 & 64.60 & 51.96 \\
\hline Group (3) & 644 & $807 \mathrm{a}$ & $836 \mathrm{a}$ & $831 \mathrm{a}$ & $714 \mathrm{a}$ & $632 \mathrm{a}$ \\
$1.5 \%$ urea & \pm & \pm & \pm & \pm & \pm & \pm \\
(High Dig) & 67.42 & 87.46 & 54.84 & 35.49 & 10.82 & 21.73 \\
\hline
\end{tabular}

* Means with different superscripts differ $(\mathrm{p} \leq 0.05)$.

This result was agreed (Tayyeb, 2017), (Kassem \& Abdullah, 2013) and (Birto $\&$ Broderick, 2007), and it was different with the results of (saleh \& Al-Mallah, 2013) and (Shihab, 2012).

The results also indicated significant increase $(\mathrm{p} \leq 0.05)$ in monthly milk production for the behalf of high degradable protein wich agreed with the results of (Tayyeb, 2017), (Kassem \& Abdullah, 2013) and (Biro \& Broderick, 2007) and it differs with the result of (Shihab, 2012).

Also the results indicated significant increase $(\mathrm{p} \leq 0.05)$ in commercial milk production for the behalf of high degradable protein, the result was agreed with the results of (Kassem \& Abdullah, 2013) and (Saleh \& Al-Mallah, 2013) and it differs with result of (Shihab, 2012), as seen in table (3). 
Table (3) The effect of increasing degradable Nitrogen in monthly and commercial milk production $(\mathrm{Kg})$

\begin{tabular}{|c|c|c|c|}
\hline \multirow{2}{*}{ Total milk } & \multicolumn{3}{|c|}{ Treatments groups } \\
\cline { 2 - 4 } production & Group (1) & Group (2) & Group (3) \\
& 0\% urea & $0.75 \%$ urea & $1.5 \%$ urea \\
& Low Dig. & Med Dig. & High Dig. \\
\hline Monthly milk & $41.87 \mathrm{~b}$ & $44.12 \mathrm{~b}$ & $59.83 \mathrm{a}$ \\
production & \pm 4.014 & \pm 2.557 & \pm 3.695 \\
\hline Commercial milk & $18.538 \mathrm{c}$ & $21.515 \mathrm{~b}$ & $32.887 \mathrm{a}$ \\
production & \pm 1.742 & \pm 1.942 & \pm 2.122 \\
\hline
\end{tabular}

* Means with different subscripts horizontally differ $(\mathrm{p} \leq 0.05)$.

May be the reason of the increase in milk production was the addition of urea which gave the animal the necessary nitrogen to produce the microbial protein which caused this significant in crease in milk production.

\section{Milk Components:}

The result indicated non significant differences in milk components (fat, protein, lactos, S.N.F) and that mean there were no significant effect on the level of decomposition as seen in table (4). These results a greed with that of Tayyeb (2017), Saleh \& AL-Mallah (2013) and Shihab (2012).

Table (4) The effect of increasing degradable Nitrogen in milk components

\begin{tabular}{|c|c|c|c|c|}
\hline $\begin{array}{c}\text { Homologous } \\
\text { groups }\end{array}$ & $\begin{array}{c}\text { Fat } \\
\%\end{array}$ & $\begin{array}{c}\text { Protein } \\
\%\end{array}$ & $\begin{array}{c}\text { Lactose } \\
\%\end{array}$ & $\begin{array}{c}\text { S.N.F } \\
\%\end{array}$ \\
\hline Group (1) & 4.78 & 4.35 & 5.14 & 11.58 \\
0\% urea & \pm & \pm & \pm & \pm \\
(Low Dig) & 0.144 & 0.058 & 0.083 & 0.133 \\
\hline Group (2) & 4.81 & 4.32 & 5.21 & 11.64 \\
0.75\% urea & \pm & \pm & \pm & \pm \\
(Mid Dig) & 0.212 & 0.053 & 0.100 & 0.096 \\
\hline Group (3) & 4.79 & 4.34 & 5.22 & 11.70 \\
1.5\% urea & \pm & \pm & \pm & \pm \\
(High Dig) & 0.238 & 0.033 & 0.113 & 0.126 \\
\hline
\end{tabular}

* Means with different subscripts vertically differ $(\mathrm{p} \leq 0.05)$. 


\section{دراسة تأثير الزيادة في النيتروجين المتحلل المتناول من اليوريا في علائق التعاج العواسية في إنتاج الحليب ومكوناته

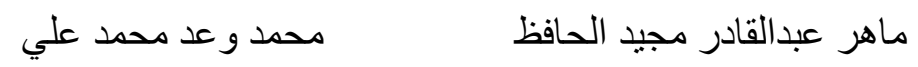

Email: Mohammed.waad88@gmail.com

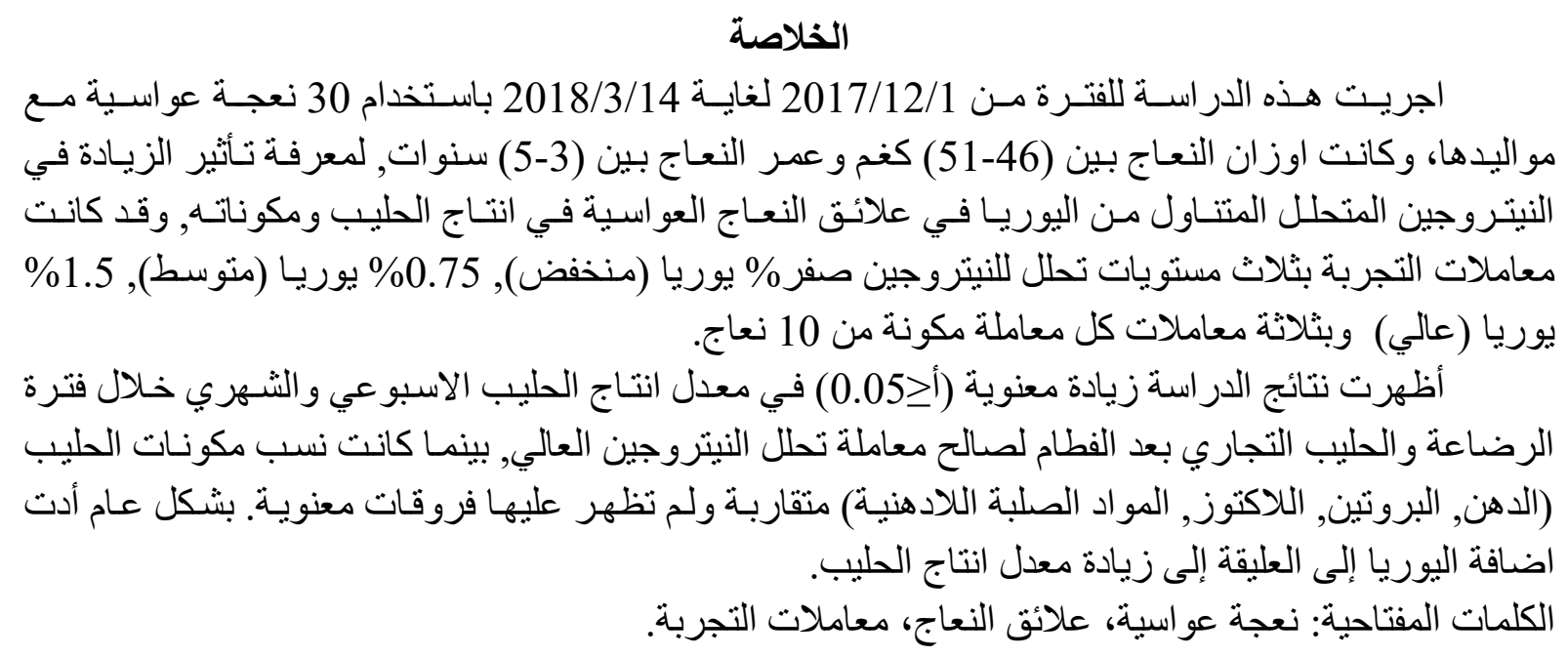

\section{تاريخ تسلم البحث 2018/12/9، وقبوله 2019/1/21 REFERENCES}

Al-Hafz, Maher A. K. (1992). The effect of different levels and sources of crude protein in the ration of lactating dairy cows on milk production and composition. Ph. D. Thesis, College of Agriculture and Forestry, University of Mosul.

Al-Khawaja, A. K., Elham A. AL-Bayati and Sammir A. M. (1987). Chemical composition and nutritional value of Iraqi feed materials- Direct Orate Of Animal Wealth. Ministry of Agriculture - Republic of Iraq.

Al-Rawi, K. M. and Abdel-Aziz M. K. (1980). Design and Analysis of Agricultural Experiments. Dar Al-Kutub Printing And Publishing, College Of Agriculture and Forestry.

Al-Saegh, Mozafer N. R. and Jalal, E. Al-Kass (1992). Sheep and Goats Production. University of Basrah.

AOAC. Association of Official Analytic Chemists (2002). Official Methods of analysis 13th . Ed., Washington D C.

Birto, A. F. and G. A. Broderick (2007). Effect different protein supplements on milk production and nutrient utilization in lacting Dairy cows. Journal of Dairy Sci. 90 (40): 1818-1827.

Duncan, D.B. (1955). Multiple range and multiple F test. Biometrica, 11: 1-42. 
FAO, (Food and Agriculture Organization). FAO data base (2006).

Kassem, M. M. and Mohammed N. Abdullah (2013). Effect of estimated by - pass protein level in concentrated rations on performance of lactating awassi ewes pre - weaning. Mesopotamia Journal of Agriculture (41)1: 154-163.

Lafi, S. Q. A. Q. Talafha ; N. Giadinis ; E. Kalait Zakis; K. Ourliotis and N. Panousis (2009). Factor affecting the reproductive performance of Awassi sheep flock in north - east of Jordan : An epidemiological study. Trop Anim. Health prod: 1755-1764.

Saleh, A. M. and Omar D. Al-Mallah (2013) Effect of rations content from undegradable protein and energy on milk production, component and some blood parameters in cows. Mesopotamia Journal of Agriculture (41)3: 122128.

SAS (2003). Statistical Analysis Systems. Software, V. 9.2, SAS Institute, Cary, NC.

Shihab L. Safwan (2012). Effect of degradable and undegradable protein in take in milk production components and some blood parameters in awassi ewes. Journal of Tikrit University for Agriculture (12) 2: 14-20.

Tayyeb, Mothanna A. (2017). Effect of bentonite supplementation with different level of urea in awassi ewes rations on milk production and constituents. $J$. Jordan Agric Sci (13) 2: 555-560. 